ISSN 2236-0859

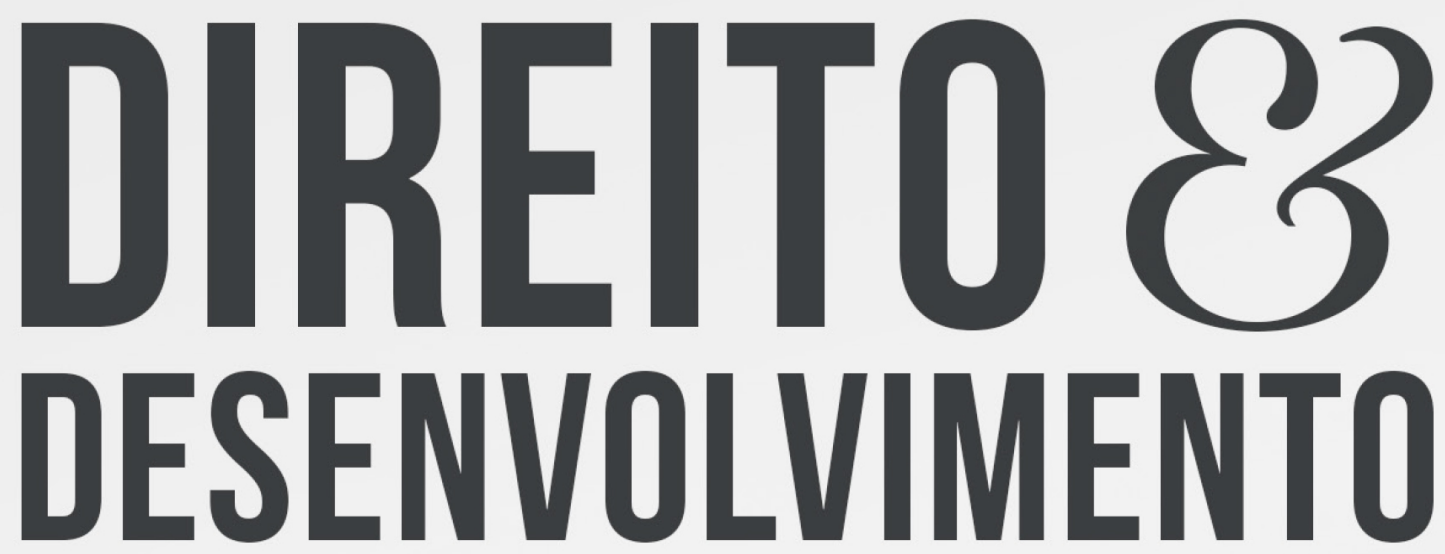

REVISTA DO PROGRAMA DE PÓS-GRADUAÇ̃̃O EM DIREITO MESTRADO EM DIREITO E DESENVOLVIMENTO SUSTENTÁVEL

ENVIRONMENTAL LAW \& COMPETITION LAW: CONFLICTS \& COMPLEMENTARITIES FROM AN ENVIRONMENTAL ECONOMICS PERSPECTIVE

ROMANA COÊLHODE ARAÚJO

JORGE MADEIRA NOGUEIRA 


\title{
ENVIRONMENTAL LAW \& COMPETITION LAW: CONFLICTS \& COMPLEMENTARITIES FROM AN ENVIRONMENTAL ECONOMICS PERSPECTIVE ${ }^{1}$
}

\section{DIREITO AMBIENTAL \& DIREITO DA CONCORRÊNCIA: CONFLITOS \& COMPLEMENTARIDADES DO PONTO DE VISTA DA ECONOMIA AMBIENTAL}

Received: 20/04/2020

Approved: 07/07/2020
Romana Coêlho de Araújoº Jorge Madeira Nogueira ${ }^{3}$

\begin{abstract}
:
The aim of this paper is to evaluate whether environmental restrictions or requirements are considered in competition law. Common sense conceives that a company that bears costs of complying with environmental requirements experiences increased costs and seeks to transfer it to the prices of its products. A possible consequence of this behavior is its effects upon the competitive position of the company in the market. Thus, the interface between environmental requirements and competition law is enhanced. Companies that disobeyed environmental regulations would have a hypothetical competitive advantage over companies in the same sector that obeyed it. Would this situation require (greater) oversight of compliance with environmental laws for all companies to observe and comply with such legislation? Or, alternatively, is it necessary to aggravate/mitigate penalties in competition law of those who have failed/fulfilled in environmental law? In this context, the paper focuses on the second question and investigates environmental implications of competition law. It initially shows that there is no immediate response in the specialized literature. We review legal and economic references to display arguments of those scholars who believe that a certain dialogue between the environment and competition is possible and of those scholars that, on the other hand, understand that they are elements not compatible or even conflicting. Finally, we estimate economic costs of the mutual lack of attention between these two branches of law using case studies from the Brazilian reality.
\end{abstract}

Keywords: Competition Law. Environmental Law. Economics. Competitive Advantage.

JEL Codes: K21, K32, Q50

\footnotetext{
1 A preliminary and partial version of this paper was accepted to an oral presentation at the 89th International Atlantic Economic Conference, that would take place in Rome, Italy, 25-28 March 2020. The Conference was cancelled due to the coronavirus pandemia. It is based upon an unpublished academic work, presented by the first author under the title "Interface between Environmental Law and Competitive Law" in the UniCeub Law course as a requirement for approval in the discipline Monograph III. Advisor Prof. Dr. Ivo T. Gico Júnior.

2 Master in Economics (UnB), Bachelor of Law (UniCEUB), MPF Server and Researcher of UniCEUB Environmental Law Research Group. Email:rca0406@gmail.com

3 Full Professor at the Department of Economics at the University of Brasília (ECO / UnB). Graduated in Economics from the Federal University of Rio de Janeiro (1975), Jorge Madeira Nogueira obtained his Master's degree in Production Engineering from the Coordination of Graduate Programs in Engineering at the Federal University of Rio de Janeiro (1978) and his doctorate in Agrarian Development - University of London (1982). He joined the professor in the Department of Economics at the University of Brasilia (ECO / UnB) in 1983. Between 1991 and 1995 he was Visiting Professor at Cornell University in the United States.. E-mail: jmno702@ gmail.com
} 


\section{RESUMO:}

O objetivo deste artigo é avaliar se restrições ou requisitos ambientais são considerados no direito da concorrência. $\mathrm{O}$ senso comum concebe que uma empresa que arque com custos de cumprimento das exigências ambientais experimenta custos elevados e busca transferi-los para os preços de seus produtos. Uma possível consequência desse comportamento materializase em efeitos sobre a posição competitiva da empresa no mercado. Assim, a interface entre os requisitos ambientais e a lei da concorrência é aprimorada. As empresas que desobedecessem às regulamentações ambientais teriam uma vantagem competitiva hipotética sobre as empresas do mesmo setor que a obedecessem. Essa situação exigiria (maior) fiscalização do cumprimento das leis ambientais para que todas as empresas observassem e cumprissem tal legislação? $\mathrm{Ou}$, alternativamente, seria necessário agravar/mitigar as penalidades no direito de concorrência daqueles que falhassem/cumprissem o direito ambiental? Nesse contexto, o artigo foca na segunda questão e investiga as implicações ambientais do direito da concorrência. Inicialmente mostra que não há resposta imediata na literatura especializada. Revisamos referências jurídicas e econômicas para mostrar argumentos daqueles estudiosos que acreditam que um certo diálogo entre meio ambiente e competição é possível e daqueles estudiosos que, por outro lado, entendem que são elementos não compatíveis ou mesmo conflitantes. Por fim, estimamos os custos econômicos da mútua falta de atenção entre esses dois ramos do direito utilizando estudos de caso da realidade brasileira.

Palavras-chave: Direito da Concorrência. Direito Ambiental. Economia. Vantagem Competitiva. Códigos JEL: K21, K32, Q50.

\section{INTRODUCTION}

This paper assesses whether environmental restrictions or requirements are considered in competition law. Common sense leads one to imagine that a company that bears the costs of complying with environmental requirements will probably raises its costs and, under certain conditions, it can transfer this cost increase to the prices of its goods or services. This leads to the supply of products to the market at less competitive prices, given that not all active companies (in the same market and in the same sector) comply with such environmental obligations and, therefore, their costs tend to be lower. As a consequence, these additional costs can affect the company competitive position in the market. In other words, it is often the case that an environmentally friendly product is born with possible reduction in competition.

Would this dilemma require (greater) oversight of compliance with environmental laws in order for all companies to observe and comply with such laws? Or, is it necessary to aggravate / attenuate punishments in the competition law for those who did not comply with the environmental law? This research focuses with greater interest on the second question, since the first examines ways to enforce legislation. In other words, we seek answer to a basic inquiry: what are the implications of environmental law on competition law? It is a relevant issue for both environment and competition frameworks as well as to producers and consumers of "environmentally friendly products" and their "fair prices".

In developing countries this topic is little discussed. However, in the European Union - EU, even though many lawyers and economists reject the idea that environmental concerns should play a significant role in competition policy, the issue has been discussed and public policy makers have been asked to demonstrate the importance of environmental factors in 
construction competition law. In such circumstance, Economics can play a relevant role. The contribution of environmental and/or ecological economists with regard to environmental assessments, efficiency and externalities can illuminate arguments related to the topic.

Studies in the European Union point out that the intersection of competition and the environment is not an abstract, or static, theoretical issue. Competition authorities consider environmental issues in their daily work, but so far only provide special consideration for their impacts. Both (competition and the environment) have different means, but share common objectives in terms of maximizing social well-being and correcting market failures. They also identify that the relationship between environmental concerns and anti-competitive behavior is fragile and can be highly specific to each case. Another relevant aspect pointed out by the European studies is that economic objectives of the Treaty on the Functioning of the European Union - TFEU should not be more important than environmental goals and targets.

To study possible intersections between these two branches - environment and competition -, regulated by legal instruments and from the economic perspective, are of interest of this article. Hence, we analyze how the United States and the European Union address the issue, by visualizing how to treat environmental and competitive variables. In complement, we look at the reality of Latin law, we survey Brazilian authors that are notoriously recognized in Competition Law, Environmental Law, and Economics.

We start conceptualizing Competition and Environmental Laws. Next, we will deal specifically with the interface between Environmental Law and Competitive Law. To glimpse what is currently the intersection of these branches of law, it is necessary to point out the outcome of a quantitative survey conducted within the Administrative Council of Economic Law (CADE) of Brazil, about how many administrative processes involved the environmental variable in its analysis since 200o. Finally, we discuss the possibilities of overlapping of these two branches of law in order to indicate that keep them apart implies negative economic consequences.

\section{CONCEPTUAL CHARACTERISTICS OF COMPETITION LAW}

Competition law is the set of legal rules designed to investigate, repress and prevent the various modalities of abuse of economic power, in order to prevent monopolization of markets and promote free initiative in favor of the collective. From an economic perspective, competition assumes the following functions: economic optimization, technological advances, conducting economic phenomena and flexibility of adaptation. These functions are effectively accomplished by competitive actions established by rational agents operating rationally in a free market.

Nowadays, competition is studied and investigated by many scholars from different areas of science ${ }^{4}$. Forgioni (2013) considers that there is no noteworthy enterprise that does not know that a cartel is unlawful or even ignores the need for notification to public authorities when there is a certain market concentration. Does the same knowledge of illicitude occur in environmental arena? Forgioni (2013) points out that the principle of defense of the environment in the structuring of the economic order frequently makes express reference "to differentiated treatment according to the environmental impact of products and services and their processes of elaboration and provision".

In spite of the fact that this interpretive nature of unlawful behavior of agents is also perceived in other arenas (such as reducing social inequalities, the search for full employment

4 For an analysis from a legal perspective of relationships between regulation, competition law and competitive market see Cavalcanti and Catão (2017) in a previous paper in this journal. 
and the favored treatment of small businesses), the interpretation of acts of economic agents from the perspective of violations should be carried out based upon all principles of economic order. Nevertheless, it is worth mentioning that the law provides the need to use analytical models to analyze a company's behavior as a market agent.

Therefore, in several segments in which the study of competition applies it becomes stimulating to use models to discuss the social reality, considering that the focus of analysis often ceases to be competition as a balancing mechanism and moving to competition as a dynamic process. It is worth noting that competition in the latter differs from competition in the former. As an example of the latter, some authors (see for example JABBOUR, TEIXEIRA, JABBOUR and FREITAS) state that environmental management has positive effects on the operational performance of companies, since it tends to maximize the productivity of inputs and the use of organization resources, as well as to reduce costs of production. Such debate is known as "being green is being competitive". However, little is said of environmental management practices in operational performance. The same seems to occur in the field of competition.

\section{CONCEPTUAL CHARACTERISTICS OF ENVIRONMENTAL LAW}

"Environmental law is a systematizing law, which articulates legislation, doctrine and jurisprudence, concerning the elements that integrate the environment. It seeks to avoid the isolation of environmental themes and their antagonistic approach. It is no longer a question of building a water law, an atmosphere right, a land law, a forest law, a right of fauna or a biodiversity right. Environmental law does not ignore what each matter has specific, but seeks to interconnect these issues with the mortar of the identity of the legal instruments for prevention and repair, information, monitoring and participation". This a brilliant definition of environmental law by Michel Prieur apud Machado (2015, p. 18)

Environmental law has gradually evolved and gained autonomy as a branch of Legal Science with its own principles. Despite its short live it has enshrined as a fundamental human right. It is consecrated as such given the threat to human life and major environmental problems, such as availability of water in adequate quantity and quality, climate change, management of solid waste, reduction of biological diversity, and contamination of air and water by chemicals. Even so, it is common for Judiciaries to interpret several environmental laws in a restrictive manner and to apply them more positively (legal positivism), failing to consider the legal principles, especially the most important principles of environmental law.

Machado (2015) expresses this, arguing that the environment is the expression of an overview of the intentions of human beings and of relationships among them and between them and their environment. In such a context, it is not surprising that the right to a healthy environment is a right of horizontal character, which covers the different classical branches of law (civil law, administrative law, criminal law, international law) and a right of interactions, which is dispersed in various regulations. More than a new branch of law with its own rule, the environmental law tends to penetrate all existing legal systems to guide them in an environmental sense.

This is particularly true in the Brazilian reality, where its Federal Constitution of 1988 highlights the importance of the environment and its protection, in order to translate itself as an ideal of a (collective) social right that can no longer be relegated to a second role. Also in the Brazilian Law of Environmental Crimes (Law no. 9,605, February 12, 1998) there are provision for criminal and administrative sanctions derived from conducts and activities harmful to the environment. 


\section{COMPETITION AND ENVIRONMENTAL LAW: CONFLICTS AND COMPLEMENTARITIES}

To identify and analyze conflicts and complementarities between these two branches of law, it is necessary to explicit a concept of development. If one follows Amartya Sen, development consists of the elimination of deprivations of liberty that limit people's choices and opportunities to exercise their condition as an agent, competition law can be considered as freedom (or not). In this approach of development as freedom, competition is important regardless of whether or not, because it generates economic effects, as it guarantees important freedoms to the development process such as freedom of initiative or of choice (MUNHOZ, 2006).

However, if the definition of development is a reductionist view as zero economic growth, as in Herman Daly, it is perceived that the relationship between environmental and competitive law is non-existent. That is, there is a distorted vision of sustainability, because it only considers material wealth (GERBRANDY, 2012). This also implies having a narrow view of the concept of consumer welfare, which is to obtain material goods at non-increasing prices, as it does not incorporate the environment as consumer's welfare. Therefore, if the well-being of consumption is only material wealth; and if development entails sustainable losses, then sustainability does not come into the competition law, because there is incompatibility of the competition law and sustainability ${ }^{5}$. Thus, the investigation of possible environmental implications in competition law begins and depends upon the concept of economic development.

In such scenario, the limits between obeying, or not, a legislation are influenced by economic factors. Based upon the price theory, it is possible to support a relationship between the law and the behavior of economic agents influenced by a law, since the law regulates sanctions and rewards for a given conduct. These poles - legal or illegal acts - are choices of people who take into account the advantages/disadvantages of crime. However, such isolated choices contaminate and influence other economic agents in different markets and places.

Solomon Filho (2007) points out that a competitive law, in its institutional conception, does not seek a result, or economic effect, but guarantees a loyal relationship between competitors and that there is competition effectively (and not typical power relations in free markets). This enables economic agents to perceive the best options and order relationships more fairly and balanced. Solomon Filho (2007) also argues that a consumer interest is complex. It has essential needs such as health, education, as well as the preservation of the environment. This implies that his concern (from consumer) is not limited exclusively to the economic dimension.

These aspects are also observed in the regulation of human activities that affect the natural basis on which we live. In such situation, environmental factors seem to change the composition of the cost of a product or service to be made available in the market. However, there is another possible situation; environmental legal requirement motivates innovation. This, in turn, induces a company to obtain competitive gains in the face of a technological gain. In such situation, it is worthwhile to protect the environment either by administrative regulation or by legislative action through laws of responsibility, right of ownership and/or limits of emissions to the environment (HUSSEN, 1999). Additionally, consumers may be willing to pay more for green products. Theoretically, a free market should pressure producers and suppliers to compete for environmental quality. Thus, a new relationship is established,

5 Gerbrandy (2012, p.5): "The tension between these two concepts seems apparent: competition law is aimed at greatest economic efficiency and the maximization of consumer welfare on the short term, whereas sustainability is aimed at incorporating non-economic elements, such as environmental and societal concerns, into a long-term vision of society. Competition law seems, therefore, one of those obvious candidates for change to organize society on a sustainable footing". 
marked by the partnership of economic and environmental interests aimed at sustainable development.

In contrast, Wilk (2013) examines whether policymakers could improve the effectiveness of their decision using (environmental and ecological) economists' contribution with regard to possible negative environmental assessments, in searching for efficiency and to internalize externalities, based upon the growing use of economic regulations of markets in parallel with the development of environmental policy in the European Union. To this end, he analyzes cases related to waste disposal, energy savings and sustainable use of natural resources. These cases indicate the need to perform Cost Benefit Analysis - CBA, aiming to point out (economic) efficiency in line with the Treaty on the Functioning of the European Union - TFEU.

The TFEU forbids agreements between firms which may harm trade between Member States and which have the effect of preventing, restricting or distorting competition on the internal market (Art. 101). It follows that Article 102 inhibits abuse of the dominant position if this is detrimental to that trade (FORGIONI, 2013, p. 131). However, paragraph 3rd of Article 101 brings an exception to the prohibition of any agreement between undertakings that could affect trade between Member States (agreements with anti-competitive effects) if these negative effects are overcome by gains (benefits) of efficiency.

Wilk (2013) points out that more importantly, in recent years, EU competition authorities, driven by an efficiency criterion, agreed that the central importance of competition law is consumer welfare. Thus, we perceive the importance and impact of economic theory on competition law 6 . This exception in the European Union seems, in a way, to highlight the limits of an environmental policy in confrontation with competitive policy provided that there is gain in efficiency. However, it is surprising that little few is discussed in the literature about the existing relationships between environmental law and competitive law ${ }^{7}$. That is, can environmental legislation cohabit the same setting as competition law? What are the environmental implications on competition law?

These questions are explored by Gerbrandy (2012). She points to conflicts between Europe's competition law and sustainability objectives. These conflicts result in a shock of values in a "sustainable society" and she investigates what the actual problem behind these conflicts, since there are immediately two possible solutions: a) to change competition law to accommodate sustainability; or b) to remove sustainability restrictions. Gerbrandy does not recognize her limited concept of sustainability (as meaning zero growth from $\mathrm{H}$. Daly) and her perception of competition law as exclusively based upon economic aspects, in particular on increasing consumer material well-being.

It is evident that she uses two concepts that present distortions. As we pointed out earlier first, there is a narrow view of the concept of consumer well-being, which is restrict it to material goods at non-increasing prices, as it does not incorporate the environment as 6 WILK, Bartlomiej S. The Application of Environmental Policies to Competition Law. What can be the influence of environmental and ecological economics in the balancing of article 101(3) TFEU? Assessmant on the example of energy savings, waste disposal and natural recources use cases. Poland: Het Europa Instituut Utrecht, 2013, p 12: "The importance of economics became obvious if only looking at the key concepts of competition law derived from this science. The increased impact of economic theory can be also reasoned from even more frequent use of empirical techniques by policy makers. Most importantly, in recent years the EU competition authorities, driven by an efficiency criterion, have agreed that the central importance of competition law is consumer welfare".

7 Among Brazilian scholars, very few have addressed the subject. Guimarães (2003) considers public civil action as a possible and common instrument of protection and guardianship, both of the environment and competition. However, it does not present any relationship between such rights. Jaeger Junior (2013) sets out the existence of a conflict between business competition and environmental protection by examining legislative competence in the process of integrating the European Union specifically in the case with emissions of toxic gases into the atmosphere. The author explores that in economic processes of integration of the European Union, competition is a certain step ahead of the environment in terms of internal market policies, when dealing with legislative competence, except fauna and flora. Still, does he question who would have the power to issue a directive to match the competitiveness of companies with a particular product? Would it be through devices related to the common market, internal market or the environment? The solution was via the internal market, that is, the author positions that there has been an overcoming of competition policy in the face of environmental policy. However, Jaeger Junior seems to mistakenly mix concepts of competition and competitiveness. 
component of consumer's well-being. Second, there is a reductionist view of economic growth. If consumer's well-being consumption is only material wealth; and if development entails sustainable losses, then sustainability does not enter the competition law. In a framework like hers there is difficult to achieve compatibility between sustainable development, based upon an efficient and controlled exploitation of economic activities, and the defense of competition from the perspective of the precautionary principle.

It is, therefore, apparent in the international literature the maintenance of a controversy. On the one hand, there are those who point to compatibility between antitrust policy and environmental protection. On the other hand, others argue that there is no compatibility between competition and environmental considerations. The Brazilian legislation seems to be an example of the latter. This is the argument of Munhoz (2006) by saying that the Brazilian model of competition, embodied in competition law and policy, promotes, or at least can promote, development. Since its elements and objectives are compatible with the pursuit of development - this is understood as a process, in which freedoms (such as initiative or choice) constitute both instrument and end. Furthermore, an essential component of it, is the awareness of the importance of defending the competitive process in the market, aiming to assist in promoting the development process and not any defense of competition.

A less optimistic view is that by Forgioni (2013), who reminds us that agreements between economic agents often tend to enable the reproduction of monopolistic conditions. For this reason, they are traditionally regulated by antitrust laws. In this sense, companies operating in the same relevant market tend to conclude (horizontal) agreements in order to neutralize competition between them. Therefore, it remains to be known whether such agreements between competitors allow a gain only to the companies involved (players) or if the same gain reaches consumers as environmental requirements have been met. In this case, is it possible to talk about environmental gain/benefit in the face of an illicit cartel crime? Since a cartel is undesirable to society, given that a cartel is an agreement to fix prices or quantities.

Responsibility for preserving the environment, in order direction, is not only individual, but, on the contrary, collective, in charge of humanity, without exception. This is one of the most prominent and important issues lately. This global responsibility stems from the fact that the political, historical and geographical division of peoples is not respected by the forces that make up the environment. However, in terms of regulation, some economists position that the main advantage when using environmental (or green or ecological) tariffs or taxes is that they allow the correction of market price distortions by incorporating environmental and environmental costs to them and costs due to pollution generated in the production process. It would be a pricing mechanism and consideration of the polluter pays principle that internalizes possible externalities (ROCHA, 2014, e MARTINS and ROSSIGNOLLI, 2018).

In this context, it is worth mentioning the results of the analysis of two authors from Kansai University, Osaka, Japan. They examine the effects of antitrust policy (the prohibition of price discrimination of inputs in two cases) when an emission fee is used for environmental protection. In the first case, the Environmental Protection Agency-EPA uses the same emissions tax rate, regardless of the pricing regime. In the second, the EPA differentiates between the tax rates of two pricing schemes aimed at maximizing social welfare. In both cases, the authors demonstrate that antitrust policy (regarding the prohibition of an entry price) reduces total emission and improves social well-being. In addition, it increases the effectiveness of pollution taxation. That is, there were two gains in well-being: production and environmental efficiency. They demonstrate that antitrust policy reduces the emission of pollutants and improves social well-being by contributing to environmental protection ${ }^{8}$.

8 MATSUMOTO, Shigeru; SUGETA, Hajime Antitrust Policy and Environmental Protection: Economics Bulletin, Osaka, Japão, v.17, n. 2, p. 1-10, 2007 . 


\section{LAW AND ECONOMICS PERSPECTIVE - A BRAZILIAN CASE STUDY}

/A survey carried out at the Brazilian Administrative and Economic Council for Defense of Competition (CADE) revealed a small number of references to environmental issues in its defense of completion analyses, whether in conduct or in concentration. Depending on the data search on the CADE website, it is possible to identify 38 documents (out of 677 processes or $5,6 \%$ ) involving the term "environment" between 2000 and 2019, i.e. for the last almost twenty years ${ }^{9}$. After analyzing all of them, we identified just 15 (fifteen) administrative processes that address the environment in their analyses, whether direct or indirectly.

Furthermore, it is worth noting that the research carried out with the keyword "environment" was not able to include some administrative processes that necessarily permeate the environmental variable. Most of the environmental approach occurs in reports from competing companies such as: i) in the complaint of the competitor for an environmental crime; ii) explanations about the purpose and characteristics of the product offered on the market; or iii) adjustments and union between companies in order to reduce regulatory costs and increase environmental. It happens that CADE warns in 2 or 3 processes, that there are special regulatory requirements of environmental and health surveillance agencies, or even, for such bodies to review their saturation capacities in the environment in order not to have such a small market.

It is clear that rarely an environment assessment analysis is carried out by CADE. Not even, he asked the county or state environmental agencies about the support capacity or limit of saturation of the area to receive a given operation from the act of concentration. It is necessary that such decisions do not remain sealed in the "competitive regulation" body given that there is an overlap of business and environmental activities. Iit remains to be seen why CADE does not consider in its decisions the analysis of the possible competitive implications upon the environmental law, since CADE itself enables the economic and financial enlargement of a company.

It is true, however, that analyzing environmental mergers and conduct at CADE would not completely remove environmental damage and would not even refute products that are neglected environmentally in the market. Nevertheless, states and counties could work in line with the concerns of environmental agencies aiming at fair competition in a healthy environment. Volkswagen's collective fraud in adulterating its diesel vehicles around the world is notorious as an example that shall not be followed ${ }^{10}$. In a much smaller scale, there are also Brazilian examples of the consequences of neglecting the interfaces competition law and environmental law.

An administrative process, known as the Sand Cartel, prompted the Public Prosecutor's Office of the State of Paraná (Loanda district) to sign a Conduct Adjustment Term (TAC) ${ }^{11}$, on May 24, 2000, with some sand extracting companies aiming to preserve and recover the areas of permanent preservation located on the banks of the Paraná River, municipalities of São Pedro do Paraná, Porto Rico and Marilena (State of Paraná, Brazil). Thus, an association was created to comply with the terms of the TAC. However, they took advantage of the association's

\footnotetext{
9 The result of the research carried out in CADE: 2 preparatory procedure; 3 administrative inquiry, 1 ordinary concentration act; 15 administrative proceeding and 6 summary merger act.

10 The fraud, discovered in September 2015 by the US environmental agency (EPA), attempted to manipulate pollutant emissions tests by installing software in their cars. This affected 11 million cars in the world, those expected to emit nitrogen oxides up to forty times higher than allowed in the United States of America; as well as economic consequences such as the $35 \%$ fall of its shares on the Frankfurt Stock Exchange which resulted in a loss of 26.45 billion euros. In other words, the falsification of environmental control had an impact on the market.

11 This is an administrative proceeding pending at CADE, under no 08012.004430 / 2002-43 regarding the influence of uniform commercial conduct with analysis of a cartel in the sand mining market for civil construction, in the northwest region of the State of Paraná, between 2000 to 2002.
} 
transparency structure for the practice of antitrust offenses. In other words, does CADE's analysis include the environmental obligations listed in that term? In what parameters? Let's us see.

The antitrust authority instituted an administrative proceeding on June 13, 2002, to determine the possible violation of the economic order in view of the representation of the Retail Trade Union of Hardware, Paints, Wood, Electrical, Hydraulic and Construction Materials of Maringá and Region - SIMATEC, to the detriment of sand extraction companies in the northwestern region of Paraná. The CADE alleged to the Prosecutor's Office of Paraná that nine mining companies (represented) met through an association to promote, since 2000, an artificial and simultaneous increase in the prices of the cubic meter of washed sand. There was an increase of up to $240 \%$, in the same period and without any justified reason. Furthermore, they extracted washed sand from the Paraná River to supply the entire market in the aforementioned region and used the Association of Sand Extractive Industries of the Northwest of Paraná - APA for the meetings of the alleged denounced cartel.

Among some opinions, the Federal Public Prosecutor's Office stands out, stating that the evidence in the case file was convincing for proving the conduct imputed to those represented. In addition, the justifications of those represented were not economically reasonable, which left no doubt that the conduct adopted had as its sole objective the abusive increase of prices in the period under analysis. In addition, those represented used APA meetings to exchange commercially sensitive information and agree on competitive variables, such as sales conditions.

It is clear, from the above, that in all procedural analysis of the aforementioned case, there was no discussion of the possible intersection of environmental law and competition law, but only at the end of the analysis after the vote of the Reporting Councilor. The proposal was appropriate, since the parties planned a solution that would combine the environmental concern of the MPE/PR TAC and the competitive concern arising from the transparency generated with the joint administration of the terminal. In this sense, despite the lack of collaboration with the investigation, there is a proposal to increase internal rules to promote competition in order to produce a negotiated solution to the anti-competitive impasses that permeate the terminal. Finally, the represented companies, the Environmental Institute of Paraná - IAP, and four municipalities signed a Commitment Adjustment Agreement with the Public Ministry of the State of Paraná in the District of Loanda.

That said, we ask what was the reason for the celebration of the Term of Commitment for Termination of Conduct - $\mathrm{TCC}^{12}$, since the CADE Court already had sufficient evidence to judge the case? CADE teaches us that the agreements can represent superlative gains in the investigative action, they can sabotage the union between accomplices, give immediate effect to the decision of CADE and allow this autarchy to interfere in the functioning of companies, under the competitive bias, beyond what would be possible by purely imposing means and, at the same time, allow to make this interference as less invasive as possible, since the precise details of state interference are the result of a dialogued relationship with the sanctioned.

However, the TCC was not concluded in the instructional phase or in the context of complementary instruction, but in the late procedural phase. To this end, the Court justified the exceptionality, as the parties proposed a solution that would combine the environmental concern of the MPE / PR TAC and the competitive concern arising from the transparency generated with the joint administration of the terminal. Thus, there was a plea of guilt by the

12 About TCC in Brazil. Law 12.529/11 does not regulate the matter in a specific way to sign the Term of Commitment for Termination of Conduct. It is up to the administration to define the issue by means of complementary rules ( $\operatorname{art} .85, \S_{3}$ ). Thus, the possible negotiations of agreements, represent a judgment of convenience and opportunity of the Public Administration in receiving a pecuniary contribution from the proponent in exchange for several behavioral and proactive obligations in favor of the competition, according to the position of the Rapporteur Counselor of the case in question. 
commissaries, the obligation to cease conduct, and the proposal delegated the management of the terminal by an independent third party; as well as the provision of mechanisms regarding the automatic expansion of the joint installed capacity of the terminal without the need for prior consultation with members when it reaches low idle capacity (at the terminal).

\section{FINAL REMARKS}

The environmental issue is so broad and so significant that it is one of the most prominent issues today, with discussions and attempts, in different countries and in different matters aiming at solutions, prevention and repression of the damages that result, either in rich and developed countries, or in poor and underdeveloped ones. However, in Brazil there is a lack of studies that seek to highlight the interfaces between environmental law and competition law.

The small number of processes analyzed in previous section demonstrates the little attention given to the environmental variable when analyzing competition by CADE. It is true that the laws are different and there is no apparent conflict of standards. However, the little literature points to the need for joint analysis and not to move towards a conflicting analysis. It is important to avoid negative environmental results and not only to envisage the end of undesirable anticompetitive behaviors to the market and to the collective (consumer). Therefore, it is necessary to consider that consumer well-being is not just material wealth and that development encompasses economic growth with environmental quality.

Our analysis showed some gaps in the knowledge of the topic treated - the interface between Environmental Law and Competition Law. The follow-up carried out by CADE, whether in conduct or concentration, may in a way provide an increase in the productive capacity of the companies involved. This can directly or indirectly affect the environment. And for that, it is necessary that the environmental agency at local and/or regional level must ALWAYS be asked about the support capacity or limit of saturation of the environment to receive such operation. Therefore, it is imperative that decisions are not blocked by the competitive "regulatory" body, but that there is an overlap of business and environmental activities, given that CADE itself is, in a certain way, enabling the financial and economic growth of a company.

As suggestions for future studies, we recommend researching reasons for the restriction and reduced intention to implement discussions regarding the competitive implications in Environmental Law. Furthermore, we understand that in the analysis of development, the role of elementary business ethics has to be removed from obscurity and admit a clear recognition according to Amartya Sen's warnings. It is true that this valuation is subjective, as it depends on real human behavior, but it will also be complex because it involves the personal will and the usefulness factor of this product for each individual / buyer; but before that, the product must be offered to the market in an environment that is literally clean and comes from fair and sustainable competition.

\section{REFERENCES}

ARAUJO, Romana Coêlho de. Valoração Econômica do Dano Ambiental em Inquérito Civil Público. Brasília: Escola Superior do Ministério Público da União, 2011.

BARROS, R. L. P. Gestão ambiental empresarial. Rio de Janeiro: FGV, 2013 
BASSANI, Matheus Linck. O Direito da Concorrência e a Energia Renovável: Promoção do Desenvolvimento na União Europeia. Revista Brasileira de Direito do Petróleo, Gás e Energia, v. 4, p. 3-22, 2013.

BRASIL. Lei no 9.605, de 12 de fevereiro de 1998. Lei de Crimes Ambientais. Disponível em: <http://www.planalto.gov.br/ccivil_03/leis/l9605.htm>. Acesso em: 28 abr. 2015.

BRASIL. Lei 12.529, de 30 de novembro de 2011. Lei de Defesa da Concorrência. Disponível em: $<$ http://www.planalto.gov.br/ccivil_03/_ato2011-2014/2011/Lei/L12529.htm>. Acesso em: 28 abr. 2015 .

BRASIL. Lei 6.938, de 31 de agosto de 1981. Política Nacional do Meio Ambiente. Disponível em: <http://www.planalto.gov.br/ccivilo3/leis/l9605.htm>. Acesso em: 28 abr. 2015.

BRASIL. Conselho Administrativo de Defesa Econômica. Diário Oficial da União, Brasília, DF, 31 mar, 2015. Seção 1, p. 35.

CAVALCANTI, Mariana Oliveira de Melo e CATÂO, Adrualdo de Lima. (Auto) Regulação do Mercado, Direito Concorrencial e Análise Econômica do Direito: é possível uma concorrência perfeita? Direito e Desenvolvimento, Vol. 8, No. 1, 2017, p. 179-196.

CONSELHO ADMINISTRATIVO DE DEFESA ECONÔMICA. Processo Administrativo no o8012.004430/2002-43. Brasília, 2015. Disponível em: <http: www.cade.gov.br/processual/ pesquisa $>$. Acesso em 26 abril. 2015.

DUARTE, Juliana Ferreira Antunes; SILVA, Thiago de Carvalho. Defesa da concorrência, proteção ao meio ambiente e humanismo. Revista Jus Navigandi, Teresina, ano 17, n. 3368, 20 set. 2012. Disponível em: <http://jus.com.br/artigos/22650>. Acesso em: 31 ago. 2015.

FIGUEIREDO, Leonardo Vizeu. Lições de Direito Econômico. 7 ed. Rio de Janeiro: Forense, 2014 .

FORGIONI, Paula A., Os fundamentos do antitruste, 6. ed., revista e atualizada, São Paulo: Revista dos Tribunais, 2013.

FRIEDMAN, D. Rational criminals and profit-maximizing police: Gary Becker's contribution to the economic analysis of law and law enforcement. In: Tommasi, M.; Ierulli, K. (Ed.). The new economics of human behavior. Cambridge: Cambridge University Press, 1995, p. 43-58. Disponivel em: <www.daviddfriedman.com>. Acesso em: 7 fev. 2002.

Review of economic analysis of accident law (by Steven Shavell). In: Eatwell, J.; Milgate M.; Newman, P. (Ed.). The new palgrave: a dictionary of economic theory and doctrine. Macmillan, 1987. Disponivel em: <www.daviddfriedman.com>. Acesso em: 7 fev. 2002.

GERBRANDY, Anna, Competition Law and Sustainable Development. An inquiry by legal essay, Poland: The Europa Institute Utrecht, 2012.

GICO Junior, I. T., Cartel, Teoria Unificada da Colusão. São Paulo: LEX, 2012. 
GRAU, Eros Roberto. A Ordem Econômica na Constituição de 1988. 17 ed. revista e atualizada. São Paulo: Malheiros, 2015.

GUIMARÃES, Luiz Geraldo Floeter. Ação Civil Pública na Tutela do Meio Ambiente e da Concorrência. Universo Jurídico, Juiz de Fora, ano XI, 26 de set. de 2003. Disponivel em: <http:// uj.novaprolink.com.br/doutrina/1511/acao_civil_publica_na_tutela_do_meio_ambiente_e_ da_concorrencia >. Acesso em: 2 set. 2015.

GUSTIN M.B.S.; DIAS, M.T.F. (Re)pensando a pesquisa jurídica. Rio de Janeiro: Del Rey, 2006.

HUSSEN, A. M. The economics of environmental regulation. In: Principles of environmental economics, ecology and public policy. London; New York: Routledge, 1999.

JABBOUR, C.J.C; TEIXEIRA, A.A; JABBOUR, A.B.L.S; FREITAS, W.R.S.F. "Verdes e Competitivas?" A Influência da Gestão Ambiental do Desempenho Operacional de Empresas Brasileiras. Ambiente \& Sociedade. São Paulo v. XV, n. 2, p. 151-172, maio-ago. 2012.

JURISDIÇÃO. MPF. Parecer MPF no 124. Sady d'Assumpção Torres Filho, Brasília, 2014, p. 16. Disponível em: <http: www.cade.gov.br/processual/pesquisa processual. Acesso em: 2 set. 2019.

JURISDIÇÃO. CADE. Voto CADE PA o8012.004430/2002-43. Márcio de Oliveira Junior, Brasília, 2014, item 76. Disponível em: <http: www.cade.gov.br/processual/pesquisa processual. Acesso em: 2 set. 2019 .

KIM, Hajin, The Good, The Bad, And The Ugly: Ecolabel Certification Impacts On Competition For Environmental Quality Provision, San Francisco, EUA: Stanford Law School, 2014. Disponível em:<http://ssrn.com/abstract=2394296> Acesso em: 2 set. 2015.

MACHADO, P. A. L. Direito Ambiental Brasileiro. 23. ed. rev., atual. e ampl. São Paulo: Malheiros, 2015 .

MARTINS, Regina Célia Carvalho e ROSSIGNOLI, Marisa. Desenvolvimento Econômico Sustentável. E as Externalidades Ambientais. Direito e Desenvolvimento, Vol. 9, n. 2, 2018, p. 137-154.

MATSUMOTO, Shigeru; SUGETA, Hajime Antitrust Policy and Environmental Protection.: Economics Bulletin, Osaka, Japão, v.17, n. 2, p. 1-10, 2007. Disponível em: <http:// economicsbulletin.vanderbilt.edu/2007/volumer7/EB-o6Q20004A.pdf $>$. Acesso em 2 set. 2015.

MUNHOZ, Carolina Pancotto Bohrer. Direito, livre concorrência e desenvolvimento. São Paulo: Lex Editora, 2006, p. 137.

NAZAR, Nelson. Direito Econômico e o Contrato de Trabalho. São Paulo: Atlas, 2007.

OLIVEIRA, Gesner; RODAS, João Grandino. Direito e economia da concorrência. Rio de Janeiro: Renovar, 2004.

ONU, Relatório Nosso Futuro Comum, Nova Iorque, 1987. 
POLANYI, Karl. A Grande Transformação - As origens da Nossa Época. 2ª Ed., trad. De Fanny Wrobel. Rio de Janeiro, Campus, 200o, p. 161 e 163.

ROCHA, Lilian Rose Lemos, Instrumentos Econômicos Aplicados à Regulação Ambiental: o exemplo da tributação ambiental no Brasil. Brasília: Abecer, 2014.

SALOMÃO FILHO, Calixto, Direito Concorrencial - as condutas, São Paulo: Malheiros, 2007.

SALOMÃO FILHO, Calixto, Direito Concorrencial, São Paulo: Malheiros, 2013.

SANTOS, Boaventura de Souza. A crítica da razão indolente: contra o desperdício da experiência. Para um novo senso comum: a ciência, o direito e a política na transição paradigmática. 4 ed. São Paulo: Cortez, 2002, v.1

SEN, Amartya. Desenvolvimento como liberdade. São Paulo: Companhia das Letras, 2010.

STIGLITZ, J.E.; WALH, C.E. Introdução à microeconomia. [Tradução da 3. ed. americana]. Rio de Janeiro: Campus, 2003.

WILK, Bartlomiej S. The Application of Environmental Policies to Competition Law. What can be the influence of environmental and ecological economics in the balancing of article 101(3) TFEU? Assessmant on the example of energy savings, waste disposal and natural recources use cases. Poland: Het Europa Instituut Utrecht, 2013. Disponível em: <http://renforce.rebo.uu.nl/wpcontent/uploads/2013/12/Bartlomiej-Wilk-law-and-sustainability-research-paper.pdf $>$. Acesso em 21 maio 2015 .

WILK, Bartlomiej S, The main goal of environmental policy is to limit the harmful effects of Commerce on the environment, 2013. 